Розроблено розрахунковий апарат, який дозволяє оцінювати напружено-деформований стан в процесах пластичного формозмінення, що супроводжуються складним навантаженням. Розроблені методики базуються на феноменологічному підході. При розрахунку компонент тензора пошкоджень враховано вплив немонотонності навантаження, що дозволило суттево збільиити точність розрахунку величини використаного ресурсу пластичності. Запропонований розрахунковий апарат використано для дослідження процесу радіального видавлювання з контурною осадкою

Ключові слова: пластичність металу, складне навантаження, тензор напружень, девіатор напружень, ефект Бауиингера, історія навантаження

Разработан расчётный аппарат, позволяющий оченивать напряжённо-деформированное состояние в процессах пластического формоизменения, сопровождающихся сложным нагружением. Разработанные методики базируются на феноменологическом подходе. При расчёте компонент тензора повреждений учтено влияние немонотонности нагружения, что позволило существенно увеличить точность расчёта величины использованного ресурса пластичности. Предложенный расчётный аппарат использован для исследования процесса радиального выдавливания с контурной осадкой

Ключевые слова: пластичность металла, сложное нагружение, тензор напряжений, девиатор напряжений, әффект Баушингера, история нагружения

\section{EVALUATION OF METAL PLASTICITY AND RESEARCH ON THE MECHANICS OF PRESSURE TREATMENT PROCESSES UNDER COMPLEX LOADING}

R. S i v a k

$\mathrm{PhD}$, Associate Professor

Department of Resistance of Materials and Applied Mechanics

Vinnytsia National Technical University Khmelnytske highway, 95, Vinnytsia, Ukraine, 21021 E-mail: sivak_r_i@ukr.net

\section{Introduction}

Modern advances in technology require improving available and developing and implementing new methods and procedures that make it possible to preserve material, labor, energy and environmental resources. In the metalworking industry, resource-saving is ensured by introducing a wide range of methods of cold volumetric stamping, which help increase the mechanical properties of the deformed metal and obtain products with great precision and the necessary technological properties. There are possibilities to form products with work-conducive macrostructures, strain hardening and the permissible level of deformed metal damage, which often allows replacing expensive grades of steels with cheaper ones without changing the service properties of the products.

However, the methods of theoretical solution of volumetric problems, especially in the presence of non-monotonic loading, have not been improved enough for practical use in the development and optimization of technologies. To meet the more stringent requirements for the accuracy of determining the stress-strain state, it is necessary to have information about the history of the process of plastic deformation at each point of the metal. This will allow predicting the mechanical properties of and the level of damage to the deformed metal.

The presence of non-monotonic loading considerably complicates the calculations of stresses and limiting deformations. Therefore, the development of more advanced methods for calculating the stress-strain state and esti- mating the deformability of workpieces for cold volume stamping under conditions of non-monotonic loading is an essential scientific and technical task.

\section{Literature review and problem statement}

In the field of metal forming, there are many unresolved problems associated with the evaluation of the ultimate shaping of workpieces in non-monotonic plastic deformation processes. Workpieces of the desired accuracy in shape and size can be obtained in one transition or, due to the plasticity resource depletion, in several transitions associated with intermediate annealing to restore the plasticity of the workpiece material. In the second case, non-monotonic processes of plastic shaping can be used with high efficiency, which is also connected with the formulation and solution of new problems in the theory of plasticity [1-4].

However, the effect of an increase in the plasticity of a metal by non-monotonic plastic deformation has not found wide application in engineering because of the insufficient accuracy in calculating the stress-strain state and the magnitude of the used ductile plastic resource. Therefore, in order to expand the possibilities of using this effect in industries, new theoretical developments are needed in the field of plasticity of metals

Modern methods of calculation [5-7] make it possible to determine the stress-strain state of an article at an arbitrary 
moment of the technological process at any material point, but they do not give an answer to the question of what will be the plasticity of the metal after its pressure treatment under conditions of complex loading. To predict the mechanical properties, it is necessary to calculate with sufficient accuracy the resource of metal plasticity. Until now, there has been no generally accepted method for calculating metal damage during cold non-monotonic plastic deformation. Most of the criteria are scalar and based on integrating accumulated plastic deformation along the strain path in view of various correction factors that take into account the stress state scheme but disregard the possible anisotropy of damage accumulation [8-11]. However, experimental data indicate that the accumulation of defects depends on the direction of deformation, and when the sign changes, the accumulated defects can be partially eliminated. For example, a workpiece that has got fractured under uniform stretching can then be compressed in the same direction without visible discontinuities. This fact is taken into account by tensor deformation criteria that determine the anisotropy of accumulated defects and depend on the curvature of the deformation trajectory in the deformation space. Therefore, these criteria are best suited for evaluating metal damage during cold deformation with a complex load history.

Thus, the absence of a calculating apparatus to determine with sufficient accuracy the stress-strain state and the plasticity resource of a metal under conditions of complex loading urges to undertake research in this direction.

\section{The aim and objectives of the study}

The aim of the conducted tests is to develop a calculating apparatus for determining the stress-strain state in the processes of cold volumetric stamping under complex loading.

To achieve this aim, it is necessary to solve the following objectives:

- to suggest physical equations with the help of which it is possible to increase the reliability of calculating the stressstrain state for the processes of non-monotonic loading under conditions of volumetric stress state;

- to determine the influence of physical and mechanical properties, the scheme of the stressed state and the non-monotonic loading on the plasticity of the metal, using the existing methods of experimental research;

- to develop a model of the process of damage accumulation in the case of non-monotonic deformation in conditions of volumetric stress state.

\section{Materials and methods for studying the effect of the non-monotonic loading on the ductility of a metal}

\subsection{Determination of the components of the strain} rate tensor and the stress deviator components

In the study of the non-stationary process of plastic deformation, deformation is divided into a number of stages. After each stage, the workpiece is extracted from the device and the coordinates of the nodes of the deformed grid are measured. The grid is applied to the meridian section of the workpiece. The experimental data can be represented in the form of tabulated functions (arrays) of the current (Eulerian) coordinates $z$ and $r$ from the initial (Lagrange) coordinates $z_{0}$ and $r_{0}$ and time (the number of the deformation stage). Then the workpiece is inserted into the device and deformed until the next stage. In addition, several workpieces are used with the same initial grid, and they are deformed to different stages.

The components of the strain rate tensor are determined from the distortion of the coordinate grid applied to the meridional section by the formulae [12]:

$$
\begin{aligned}
& \dot{e}_{r}=\frac{r}{r_{0}}\left[\frac{\partial z}{\partial z_{0}} \frac{\partial^{2} z}{\partial z_{0} \partial t}-\frac{\partial z}{\partial r_{0}} \frac{\partial^{2} r}{\partial z_{0} \partial t}\right], \\
& \dot{e}_{\phi}=\frac{1}{r} \frac{\partial r}{\partial t}, \\
& \dot{e}_{z}=\frac{r}{r_{0}}\left[\frac{\partial r}{\partial r_{0}} \frac{\partial^{2} z}{\partial r_{0} \partial t}-\frac{\partial r}{\partial z_{0}} \frac{\partial^{2} z}{\partial r_{0} \partial t}\right], \\
& \dot{\gamma}_{r z}=\frac{r}{r_{0}}\left[\frac{\partial r}{\partial r_{0}} \frac{\partial^{2} r}{\partial z_{0} \partial t}+\frac{\partial z}{\partial z_{0}} \frac{\partial^{2} z}{\partial r_{0} \partial t}-\frac{\partial r}{\partial z_{0}} \frac{\partial^{2} r}{\partial z_{0} \partial t}-\frac{\partial z}{\partial r_{0}} \frac{\partial^{2} z}{\partial z_{0} \partial t}\right] .
\end{aligned}
$$

We obtain the functions of Euler coordinates from the Lagrangian coordinates $z\left(z_{0}, r_{0}, t\right)$ and $r\left(z_{0}, r_{0}, t\right)$ by approximating the experimental data by cubic splines.

The yield condition under non-monotonic loading has the form

$$
\sigma_{u}^{2}=\frac{3}{2} \cdot\left(S_{i j}-\alpha_{i j}\right) \cdot\left(S_{i j}-\alpha_{i j}\right),
$$

where $\sigma_{u}$ is the intensity of stresses; $S_{i j}$ stands for the components of the stress deviator; and $\alpha_{i j}$ means the components of the microstress tensor.

According to the associated law of plastic flow,

$$
\dot{e}_{i j}=\frac{3}{2} \cdot \frac{\dot{\varepsilon}_{u}}{\sigma_{u}} \cdot\left(S_{i j}-\alpha_{i j}\right),
$$

where $\dot{e}_{i j}$ stands for the components of the strain rate tensor and $\dot{\varepsilon}_{u}$ is the rate of strain.

If the material is stretched to some deformation $e_{u}^{0}$ with a stress $\sigma_{p}$, then $\dot{\varepsilon}_{u}=\dot{e}_{11}$, and we find from (3) that

$$
S_{11}=\frac{2}{3} \cdot \sigma_{p}, \quad \sigma_{p}^{\prime}-\frac{3}{2} \cdot \alpha_{i j}^{\prime}=\sigma_{u}^{\prime} .
$$

The dashes in (4) mean that the corresponding quantities are defined for $e_{u}=e_{u}^{0}$.

The value of the accumulated plastic deformation is determined by the formula

$$
e_{u}=\int_{0}^{t} \dot{\varepsilon}_{u} \cdot \mathrm{d} \tau,
$$

where $t$ is the time of deformation.

Since equation (4) is valid for any deformation $e_{u}$, we will use it in the following form:

$$
\sigma_{p}\left(e_{u}\right)-\frac{3}{2} \cdot \alpha_{11}^{p}\left(e_{u}\right)=\sigma_{u}\left(e_{u}\right),
$$

where the index $p$ indicates that the corresponding values are determined by stretching.

If after stretching to $e_{u}^{0}$, the sample is unloaded and compressed in the direction of the previous stretching, then 
due to the Bauschinger effect, the plastic state will happen at a stress of $\sigma_{c}^{\prime}<\sigma_{p}^{\prime}$. At the same time, $\alpha_{11}$ does not change, since during the transition from stretching to compression there was no plastic deformation and since under compression

$$
\begin{aligned}
& \dot{e}_{11}=-\dot{\varepsilon}_{u}, \\
& S_{11}=-\frac{2}{3} \cdot \sigma_{c},
\end{aligned}
$$

where $\sigma_{c}>0$ is the intensity of stresses under compression.

As follows from (3),

$$
\sigma_{c}^{\prime}+\frac{3}{2} \cdot \alpha_{11}^{\prime}=\sigma_{u}^{\prime}
$$

The last equation is valid for any deformation $e_{u}=e_{u}^{0}$, if $\alpha_{11}$ is selected appropriately. Therefore, we rewrite (7) in the form

$$
\sigma_{c}\left(e_{u}\right)-\frac{3}{2} \cdot \alpha_{11}^{p-c}\left(e_{u}\right)=\sigma_{u}\left(e_{u}\right)
$$

From (4) and (7), we find that

$$
\sigma_{u}^{\prime}=\frac{1+\beta^{\prime}}{2} \sigma_{p}^{\prime}, \quad \alpha_{11}=\frac{1-\beta^{\prime}}{3} \sigma_{p}^{\prime}
$$

where

$$
\beta^{\prime}=\sigma_{c}^{\prime} / \sigma_{p}^{\prime}
$$

In studies [13, 14],

$$
\alpha_{i j}=\int_{0}^{e_{u}} b\left(e_{u}^{*}, e_{u}-e_{u}^{*}\right) \frac{\dot{e}_{i j}}{\dot{\varepsilon}_{u}}\left(e_{u}^{*}\right) \mathrm{d} e_{u}^{*} .
$$

After integrating (10) by parts, we find that

$$
\alpha_{i j}=\frac{2}{3} B\left(e_{u}, 0\right) \frac{\dot{e}_{i j}}{\dot{\varepsilon}_{u}}-\frac{2}{3} \int_{0}^{e_{u}} B\left(e_{u}^{*}, e_{u}-e_{u}^{*}\right) \frac{d^{2} e_{i j}}{d e_{u}^{2}}\left(e_{u}^{*}\right) \mathrm{d} e_{u}^{*},
$$

where $B\left(e_{u}^{*}, e_{u}-e_{u}^{*}\right)$ can be represented as follows:

$$
B\left(e_{u}^{*}, e_{u}-e_{u}^{*}\right)=f\left(e_{u}^{*}\right) \varphi\left(e_{u}-e_{u}^{*}\right) .
$$

When stretching,

$$
\frac{d^{2} e_{i j}}{d e_{u}^{2}}=0,
$$

therefore, as follows from (11) and (12),

$$
\alpha_{11}=\frac{2}{3} f\left(e_{u}\right) \varphi(0)
$$

We assume that $\varphi(0)=1$; then from (9), we find that

$$
f\left(e_{u}\right)=\frac{1-\beta\left(e_{u}\right)}{2} \sigma_{p}\left(e_{u}\right) .
$$

As follows from (11), in the process of compression after stretching,

$$
\begin{aligned}
& \alpha_{11}^{p-c}=\int_{0}^{e_{u}} b\left(e_{u}^{*}, e_{u}-e_{u}^{*}\right) \mathrm{d} e_{u}^{*}-\int_{e_{u}^{0}}^{e_{u}} b\left(e_{u}^{*}, e_{u}-e_{u}^{*}\right) \mathrm{d} e_{u}^{*}= \\
& =-\frac{2}{3} B\left(e_{u}^{0}, 0\right)+\frac{4}{3} B\left(e_{u}^{0}, e_{u}-e_{u}^{0}\right) .
\end{aligned}
$$

From (8) with allowance for (12) and (13), we find that

$$
\varphi\left(e_{u}-e_{u}^{0}\right)=\frac{\sigma_{p}\left(e_{u}\right)-\sigma_{c}\left(e_{u}\right)}{\left(1-\beta\left(e_{u}\right)\right) \sigma_{p}\left(e_{u}^{0}\right)} .
$$

Taking into account (2), (3) and (11), we obtain the equation for calculating the deviator components of the stresses in the form

$$
\begin{aligned}
& S_{i j}=\frac{2}{3} \sigma_{u}\left(e_{u}\right) \frac{\dot{e}_{i j}}{\dot{\varepsilon}_{u}}- \\
& -\frac{1}{3} \int_{0}^{e_{u}}\left(1-\beta\left(e_{u}^{*}\right)\right) \sigma_{u}\left(e_{u}^{*}\right) \phi\left(e_{u}^{*}-e_{u}^{0}\right) \frac{d^{2} e_{i j}}{d e_{u}^{2}}\left(e_{u}^{*}\right) \mathrm{d} e_{u}^{*},
\end{aligned}
$$

where $\sigma_{u}\left(e_{u}\right)$ is the flow curve; $e_{u}$ is the degree of deformation; $\beta\left(e_{u}\right)=\frac{\sigma_{0.2}\left(e_{u}\right)}{\sigma_{u}\left(e_{u}\right)}$ is the ratio of the relative yield stress to the compression $\sigma_{0.2}\left(e_{u}\right)$ after stretching the sample to the accumulated deformation $e_{u}$ by the stress $\sigma_{u}\left(e_{u}\right)$ to the latter (a parameter characterizing the Bauschinger effect); $\varphi\left(e_{u}-e_{u 0}\right)$ is the function that characterizes the hereditary influence of the loading history.

\section{2. Determination of the material characteristics} $\sigma_{p}\left(e_{u}\right), \beta\left(e_{u}\right)$, and $\phi\left(e_{u}-e_{u}^{0}\right)$

To determine the components of the stress deviator according to (16), it is necessary to determine experimentally the three characteristics of the material $-\sigma_{p}\left(e_{u}\right), \beta\left(e_{u}\right)$, and $\phi\left(e_{u}-e_{u}^{0}\right)$.

The functions $\sigma_{u}\left(e_{u}\right), \beta\left(e_{u}\right)$ and $\phi\left(e_{u}-e_{u}^{0}\right)$ can be determined under non-monotonic loading under conditions of a linear stress state $[15,16]$.

The dependences $\sigma_{u}\left(e_{u}\right), \beta\left(e_{u}\right)$ and $\phi\left(e_{u}-e_{u}^{0}\right)$ for steel 10 are determined by the method described in [16]. To do this, we use standard samples, which in the first stage we stretch to the residual deformations $0.02,0.03$, and 0.062 . Then, from the deformed samples, we cut short cylindrical specimens, which are further deposited, and we construct the corresponding stretching diagrams (Fig. 1). The parameter $\beta$, which characterizes the Bauschinger effect, is determined by the formula

$$
\beta=\frac{\sigma_{0.2}}{\sigma_{u}\left(e_{u}^{0}\right)}
$$

where $\sigma_{0.2}$ is the conditional yield point with a plastic deformation tolerance of 0.002 when the sample is compressed after it has been stretched to a deformation $e_{u}^{0}$, which corresponds to the stress $\sigma_{u}\left(e_{u}^{0}\right)$.

Fig. 1 shows the tensile (compression) of the diagram for steel 10, and Fig. 2 shows experimental dependences for the Bauschinger parameter $\beta\left(e_{u}\right)$.

The results of the tests show that the parameter $\beta$ depends strongly on the accumulated deformation $e_{u}$ at $e_{u} \leq 0.05$, and at $e_{u}>0.05$ this parameter remains constant for most metals and takes a certain value $\beta_{m}[16]$. For steel 10, $\beta_{m}=0.34$ (Fig. 2).

To approximate the dependence of $\beta$ on $e_{u}$, we used the following formula [17]: 
$\beta=\beta_{m}+\left(1-\beta_{m}\right) \exp \left(c \cdot e_{u}\right)$.

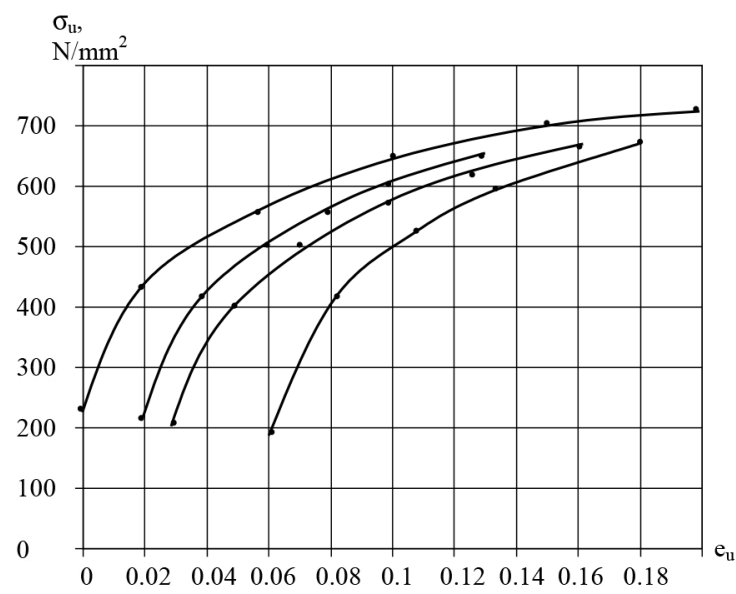

Fig. 1. The stretch and compression diagram (steel 10)

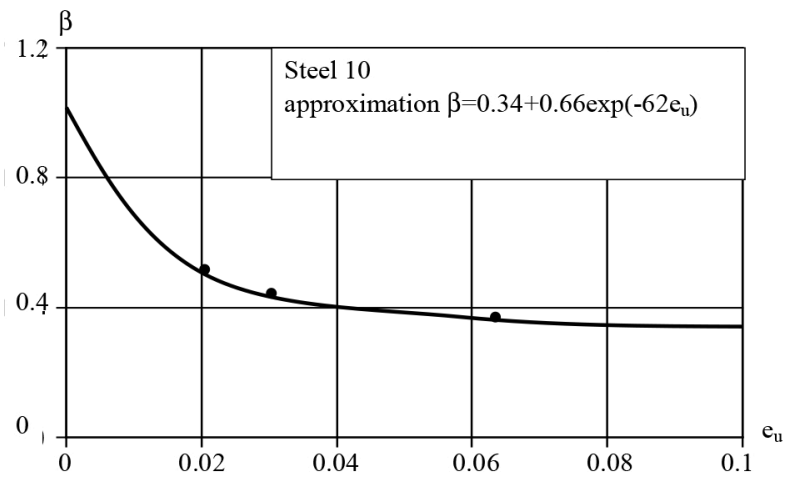

Fig. 2. The dependence of the parameter $\beta$ on $e_{u}$

Using the method of least squares, for a constant $c$, we obtain the following values: $c=-62$ for steel 10 and $c=-50$ for aluminum $\mathrm{AD}-1$.

The function $\varphi$, which allows taking into account the hereditary influence of the history of deformation on a given state of the material during plastic deformation, is also determined from the results of the study of cylindrical specimens for tension and subsequent compression. In this case, the value is determined by formula $(15)[15,16]$ :

$$
\phi\left(e_{u}-e_{u}^{0}\right)=\frac{\sigma_{p}\left(e_{u}\right)-\left|\sigma_{c}\left(e_{u}\right)\right|}{\sigma_{p}\left(e_{u}^{0}\right)\left(1-\beta\left(e_{u}^{0}\right)\right)},
$$

where $e_{u}^{0}$ is the accumulated deformation at reaching which there is an unloading or break of the deformation trajectory; $\sigma_{p}\left(e_{u}\right)$ is the stress under monotonic stretching; $\sigma_{c}\left(e_{u}\right)$ is the stress at compressing the sample before deformation $e_{u}$, previously stretched to $e_{u}^{0}$ by the stress $\sigma_{p}\left(e_{u}^{0}\right) ; \quad \beta\left(e_{u}^{0}\right)$ is the value of the Bauschinger parameter at $e_{u}=e_{u}^{0}$.

The experimental values of $\varphi$, determined by formula (19), are approximated in accordance with recommendations of [16] by the dependence

$$
\phi\left(e_{u}-e_{u}^{0}\right)=\phi_{0}+\left(1-\phi_{0}\right) \exp \left(c_{1}\left(e_{u}-e_{u}^{0}\right)^{c_{2}}\right),
$$

where $\varphi_{0}$ is the asymptotic value of $\varphi$, which was determined experimentally (for steel $10-\varphi_{0}=0.19$ ).
The coefficients $c_{1}$ and $c_{2}$ are determined by the method of least squares, and we obtain the following values: for steel $10, c_{1}=-22.3$ and $c_{2}=0.806$.

The experimental values $\phi\left(e_{u}-e_{u}^{0}\right)$ and the approximating curves are shown in Fig. 3.

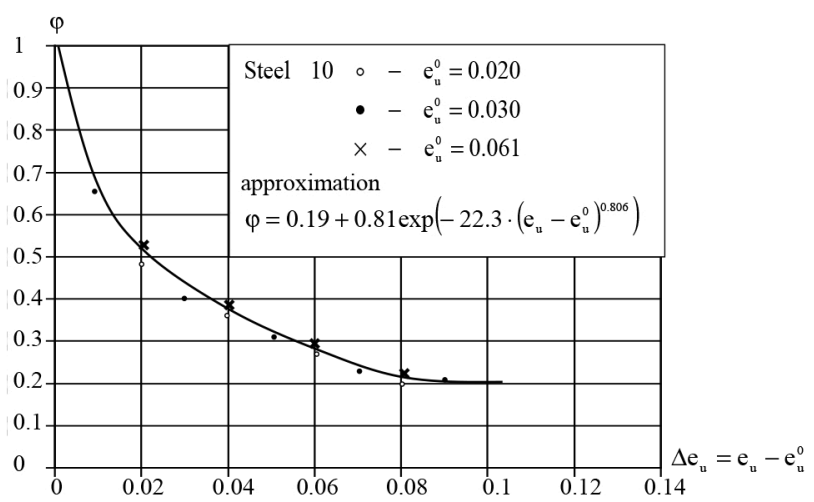

Fig. 3. The dependence of the function $\varphi$ on $e_{u}-e_{u}^{0}$

The function $\varphi$ is the main feature of the anisotropic hardening model (16). This function allows taking into account the hereditary influence of the loading history on the current state of the material during its plastic deformation.

\section{3. Evaluation of deformability of workpieces under} non-monotonic loading

In most cases, the processing of metals by pressure is accompanied by a non-monotonic plastic deformation of metals. The criteria of deformability based on the scalar model of damage accumulation processes [18-20] do not allow obtaining a reliable estimate of plasticity in such processes. As a measure of plasticity under non-monotonic loading, a boundary deformation is accepted, which is determined by the formula

$$
e_{p}=\int_{0}^{t_{p}} \dot{\varepsilon}_{u} \mathrm{~d} \tau
$$

where $\dot{\varepsilon}_{u}$ is the intensity of the deformation rates, and $t_{p}$ is the time of deformation before destruction.

In [21], to evaluate the ductility of metals under non-monotonic loading, it is proposed to use the damage tensor the components of which are determined as follows:

$$
\psi_{i j}=\int_{0}^{e_{u}} F\left(e_{u}^{*}, \eta, \mu_{\sigma}\right) \beta_{i j} \mathrm{~d} e_{u}^{*},
$$

where $\eta=\frac{3 \sigma}{\sigma_{u}}$ is the stiffness index of the stressed state; $\sigma=\frac{1}{3} \sigma_{i j} \delta_{i j}$ is the average stress, $\mu_{\sigma}$ is the Lode-Nadai parameter; $e_{u}=\int_{0}^{t} \dot{\varepsilon}_{u} \mathrm{~d} \tau$ is the degree of deformation; $t$ is the time of deformation from the moment of the onset of plastic deformation to the deformed state under consideration.

The components of the directing strain tensor of the deformations $\beta_{\mathrm{ij}}$ are equal to

$$
\beta_{i j}=\sqrt{\frac{2}{3}} \frac{d \varepsilon_{i j}}{d e_{u}}
$$


The function $F\left(e_{u}, \eta, \mu_{\sigma}\right)$ is a characteristic of the material. The destruction condition proposed in [21] has the form

$\psi_{i j} \psi_{i j}=1$

With the use of failure condition (23), solutions of the twostage, cyclic and complex loading problems have been obtained [22], which confirms the reliability of the tensor model.

The following model is proposed for describing the process of damage accumulation in the case of non-monotonic plastic deformation. Since the components of the directing tensor are determined by formula (22), then using the physical equations of the theory of plastic flow

$$
d \varepsilon_{i j}=\frac{3}{2} \frac{d e_{u}}{\sigma_{u}} S_{i j}
$$

we find that

$$
\frac{d \varepsilon_{i j}}{d e_{u}}=\sqrt{\frac{3}{2}} \beta_{i j}=\frac{3}{2} \frac{S_{i j}}{\sigma_{u}}
$$

or

$$
\beta_{i j}=\sqrt{\frac{3}{2}} \frac{S_{i j}}{\sigma_{u}}
$$

where $S_{i j}$ stands for the components of the stress deviator; $\sigma_{u}$ is the stress intensity.

We represent the tensor $\sigma_{i j}$ in the form

$$
\sigma_{i j}=\mathrm{S}_{i j}+\sigma \delta_{i j} \text {, }
$$

where $\sigma=\frac{1}{3} \sigma_{i j} \delta_{i j}$ is the average stress.

In addition, we use the well-known relations

$$
\begin{aligned}
& \mu_{\sigma}=\frac{2 S_{2}-S_{1}-S_{3}}{S_{1}-S_{3}}, \\
& S_{1}+S_{2}+S_{3}=0, \\
& 2 \sigma_{u}^{2}=\left(S_{1}-S_{2}\right)^{2}+\left(S_{2}-S_{3}\right)^{2}+\left(S_{3}-S_{1}\right)^{2} .
\end{aligned}
$$

After solving the system of (28) and (29), we find that

$$
\begin{aligned}
& \frac{S_{1}}{\sigma_{u}}=\mp \frac{1}{3} \frac{\mu_{\sigma}-3}{\sqrt{\mu_{\sigma}^{2}+3}}, \\
& \frac{S_{2}}{\sigma_{u}}= \pm \frac{1}{3} \frac{2 \mu_{\sigma}}{\sqrt{\mu_{\sigma}^{2}+3}}, \\
& \frac{S_{3}}{\sigma_{u}}=\mp \frac{1}{3} \frac{\mu_{\sigma}+3}{\sqrt{\mu_{\sigma}^{2}+3}} .
\end{aligned}
$$

It follows from (22) and (30) that the principal components of the tensor $\beta_{i j}$ are equal to

$$
\begin{aligned}
& \beta_{1}=\mp \frac{1}{\sqrt{6}} \frac{\mu_{\sigma}-3}{\sqrt{\mu_{\sigma}^{2}+3}}, \\
& \beta_{2}= \pm \frac{1}{\sqrt{6}} \frac{2 \mu_{\sigma}}{\sqrt{\mu_{\sigma}^{2}+3}},
\end{aligned}
$$

$$
\beta_{3}=\mp \frac{1}{\sqrt{6}} \frac{\mu_{\sigma}+3}{\sqrt{\mu_{\sigma}^{2}+3}} .
$$

It is assumed that, under non-monotonic loading, fracture occurs when some function of the invariants of the tensor $\psi_{i j}$ reaches a certain value. The first invariant of this tensor is zero, since due to incompressibility of the material, $\beta_{1}+\beta_{2}+\beta_{3}=0$. Without taking into account the influence of the third invariant, the failure condition can be written in the form

$$
\psi_{1}^{2}+\psi_{2}^{2}+\psi_{3}^{2}=1
$$

To determine the form of the function $F\left(e_{u}, \eta, \mu_{\sigma}\right)$, which is included in (21), we consider simple loading, for which $\beta_{i j}$, $\eta$, and $\mu_{\sigma}$ remain constant; then [21]

$$
\psi_{i j}=\beta_{i j} \int_{0}^{e_{u}^{*}} F\left(e_{u}, \eta, \mu_{\sigma}\right) \mathrm{d} e_{u}=\beta_{i j} \phi\left(e_{u}, \eta, \mu_{\sigma}\right),
$$

where

$$
\phi\left(e_{u}, \eta, \mu_{\sigma}\right)=\int_{0}^{e_{u}^{*}} F\left(e_{u}, \eta, \mu_{\sigma}\right) \mathrm{d} e_{u} .
$$

As $\beta_{1}^{2}+\beta_{2}^{2}+\beta_{3}^{2}=1$, it follows from (32) that at failure if $e_{u}=e_{p}, \varphi\left(e_{p}, \eta, \mu_{\sigma}\right)=1$.

Besides,

$$
\varphi\left(0, \eta, \mu_{\sigma}\right)=0 .
$$

Satisfying these conditions, let us assume that [21]

$$
\phi=(1-a) \frac{e_{u}}{e_{p}\left(\eta, \mu_{\sigma}\right)}+a \frac{e_{u}^{2}}{e_{p}^{2}},
$$

where $e_{p}\left(\eta, \mu_{\sigma}\right)$ is the surface of boundary deformations; $a$ is a constant the value of which depends on the mechanical characteristics of the metal. The value of $a$ is taken equal to $a=0.48$.

Satisfying relations (21), (34), and (36), we assume that in the general case [21]

$$
\psi_{1}=\int_{0}^{e_{u}}\left(1-a+2 a \frac{e_{u}}{e_{p}\left(\eta, \mu_{\sigma}\right)}\right) \beta_{1} \frac{\mathrm{d} e_{u}}{e_{p}\left(\eta, \mu_{\sigma}\right)} .
$$

Analogous expressions can be obtained for $\psi_{2}$ and $\psi_{3}$, which enter into the destruction condition (32).

\section{Results of studying the radial extrusion process followed by sagging}

A schematic diagram of the process of radial extrusion of cylindrical specimens followed by sagging is shown in Fig. 4.

The components of the stress deviator for this process are calculated using formula (16). The hydrostatic stress $\sigma$ is determined by integrating the differential equilibrium equations, which in the case of axisymmetric deformation have the form

$$
\begin{aligned}
& \frac{\partial \sigma_{r}}{\partial r}+\frac{\partial \tau_{r z}}{\partial z}+\frac{\sigma_{r}-\sigma_{\phi}}{r}=0, \\
& \frac{\partial \tau_{r z}}{\partial r}+\frac{\partial \sigma_{z}}{\partial z}+\frac{\tau_{r z}}{r}=0 .
\end{aligned}
$$




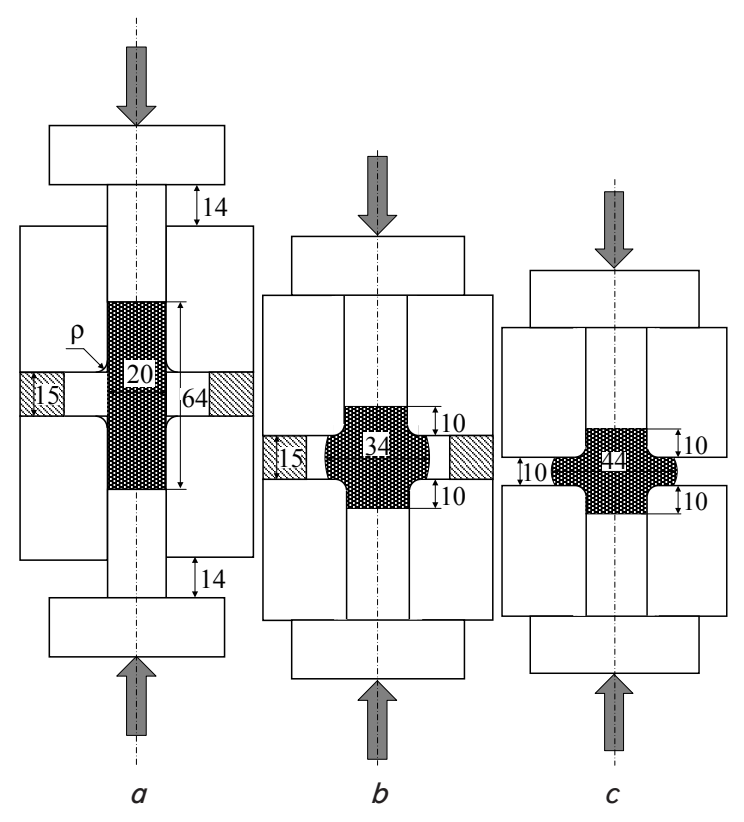

Fig. 4. A schematic diagram of the process of radial extrusion with subsequent sagging: $a-$ initial position; $b$ - radial extrusion; $c$ - contour sag of the thickening obtained after radial extrusion

We also use the integral equation of equilibrium

$$
\mathrm{P}=2 \pi \int_{0}^{R} \sigma_{z} r \mathrm{~d} r
$$

where $R$ is the radius of the deformed body; $P$ is the force that is determined when the body under investigation is deformed.

$$
\sigma_{r}=\left(\sigma_{r}\right)_{A}+\int_{r}^{R}\left(\frac{\partial \tau_{r z}}{\partial r}+\frac{S_{r}-S_{\phi}}{r}\right) \mathrm{d} r,
$$

where $\left(\sigma_{r}\right)_{\mathrm{A}}$ is the radial stress at point $\mathrm{A}$, which is on the outer surface of the workpiece.

The axial stress is

$$
\sigma_{z}=S_{z}+\sigma_{r}-S_{r}
$$

After substituting (42) and (41) for (40), we find that

$$
\left(\sigma_{r}\right)_{\mathrm{A}}=\frac{1}{\pi R^{2}}\left(\mathrm{P}-2 \pi \int_{0}^{R}\left(S_{z}-S_{r}+S\right) r \mathrm{~d} r\right),
$$

where

$$
S=\int_{r}^{R}\left(\frac{\partial \tau_{r z}}{\partial z}+\frac{S_{r}-S_{\phi}}{r}\right) \mathrm{d} r .
$$

To determine the stresses at other points of the radius, we use equation (41) in the form

$$
\left(\sigma_{r}\right)_{i}=\left(\sigma_{r}\right)_{i+1}+\int_{r_{i+1}}^{r_{i}}\left(\frac{\partial \tau_{r z}}{\partial z}+\frac{S_{r}-S_{\phi}}{r}\right) \mathrm{d} r .
$$

We calculate the stresses $\sigma_{z}$ and $\sigma_{\varphi}$ along the radius by the formulae

$$
\left(\sigma_{z}\right)_{i}=\left(\sigma_{r}\right)_{i}-\left(S_{r}\right)_{i}+\left(S_{z}\right)_{i},
$$

$$
\left(\sigma_{\phi}\right)_{i}=\left(\sigma_{r}\right)_{i}-\left(S_{r}\right)_{i}+\left(S_{\phi}\right)_{i} .
$$

Similarly, we calculate the stress along the other parallel radii. The value of the axial stress $\sigma_{z}$ along the vertical lines is determined by integrating the second differential equilibrium equation (39)

$$
\left(\sigma_{z}\right)_{i+1}=\left(\sigma_{z}\right)_{i}-\int_{z_{i}}^{z_{i+1}}\left(\frac{\partial \tau_{r z}}{\partial r}+\frac{\tau_{r z}}{r}\right) \mathrm{d} z .
$$

The results of the stress and strain calculations are used to construct the deformation pathways $\eta\left(e_{u}\right)$ and $\mu_{\sigma}\left(e_{u}\right)$ and also for calculating $\beta_{i}$ by formulae (31).

\section{Discussion of the results of the study of the radial extrusion process followed by sagging}

Fig. 5 shows the obtained dependences of the normal stresses $\sigma_{z}, \sigma_{r}$, and $\sigma_{\varphi}$ on the degree of deformation $e_{u}$ at points that, before the deformation, had occupied the positions indicated in the same Figure $(z=0)$.

From the analysis of the dependences shown in Fig. 5, it follows that in the transition from radial extrusion to the contour sag, the nature of these dependences changes sharply. If the stresses are calculated using the physical equations of the flow theory, such a change is practically not observed. Moreover, the non-monotonic loading affects the character of the curves that describe the dependence of stresses on the degree of deformation, the closer the point under study to the surface of the workpiece. Therefore, when studying the influence of the stress field and the regularities of stress variation on the deformability and other characteristics of the deformed metal, it is necessary to take into account the anisotropy of the mechanical characteristics of the metal under non-monotonic plastic deformation.

The surface of the limiting deformations for steel 10 is approximated by the following dependence [14]:

$$
e_{p}\left(\eta, \mu_{\sigma}\right)=0.68 \exp \left(0.43 \mu_{\sigma}-0.71 \eta\right) .
$$

The surfaces of the ultimate deformations of steel 10 and the strain paths of the material particles shown in Fig. 5 are shown in Fig. 6.

Calculation of the used plasticity resource $\psi$ for three points on the horizontal axis of symmetry of a cylindrical specimen with radial extrusion with a contour sag can be done by the formula

$$
\psi=\sqrt{\psi_{1}^{2}+\psi_{2}^{2}+\psi_{3}^{2}} .
$$

The results of the calculations are given in Table 1 for the flange diameter $d_{\max }=44 \mathrm{~mm}$ at $d_{0}=20 \mathrm{~mm}$, depending on the rounding radius of the matrix.

Table 1

The results of calculating the used resource of plasticity $\psi$

\begin{tabular}{|c|c|c|c|c|c|c|c|c|}
\hline \multicolumn{3}{|c|}{$\rho / d_{0}=0.05$} & \multicolumn{3}{c|}{$\rho / d_{0}=0.15$} & \multicolumn{3}{c|}{$\rho / d_{0}=0.25$} \\
\hline $\begin{array}{c}\text { Point } \\
3\end{array}$ & $\begin{array}{c}\text { Point } \\
5\end{array}$ & $\begin{array}{c}\text { Point } \\
7\end{array}$ & $\begin{array}{c}\text { Point } \\
3\end{array}$ & $\begin{array}{c}\text { Point } \\
5\end{array}$ & $\begin{array}{c}\text { Point } \\
7\end{array}$ & $\begin{array}{c}\text { Point } \\
3\end{array}$ & $\begin{array}{c}\text { Point } \\
5\end{array}$ & $\begin{array}{c}\text { Point } \\
7\end{array}$ \\
\hline$\psi_{1}$ & $\psi_{2}$ & $\psi_{3}$ & $\psi_{1}$ & $\psi_{2}$ & $\psi_{3}$ & $\psi_{1}$ & $\psi_{2}$ & $\psi_{3}$ \\
\hline 0.58 & 0.84 & 0.98 & 0.49 & 0.68 & 0.94 & 0.46 & 0.54 & 0.86 \\
\hline
\end{tabular}



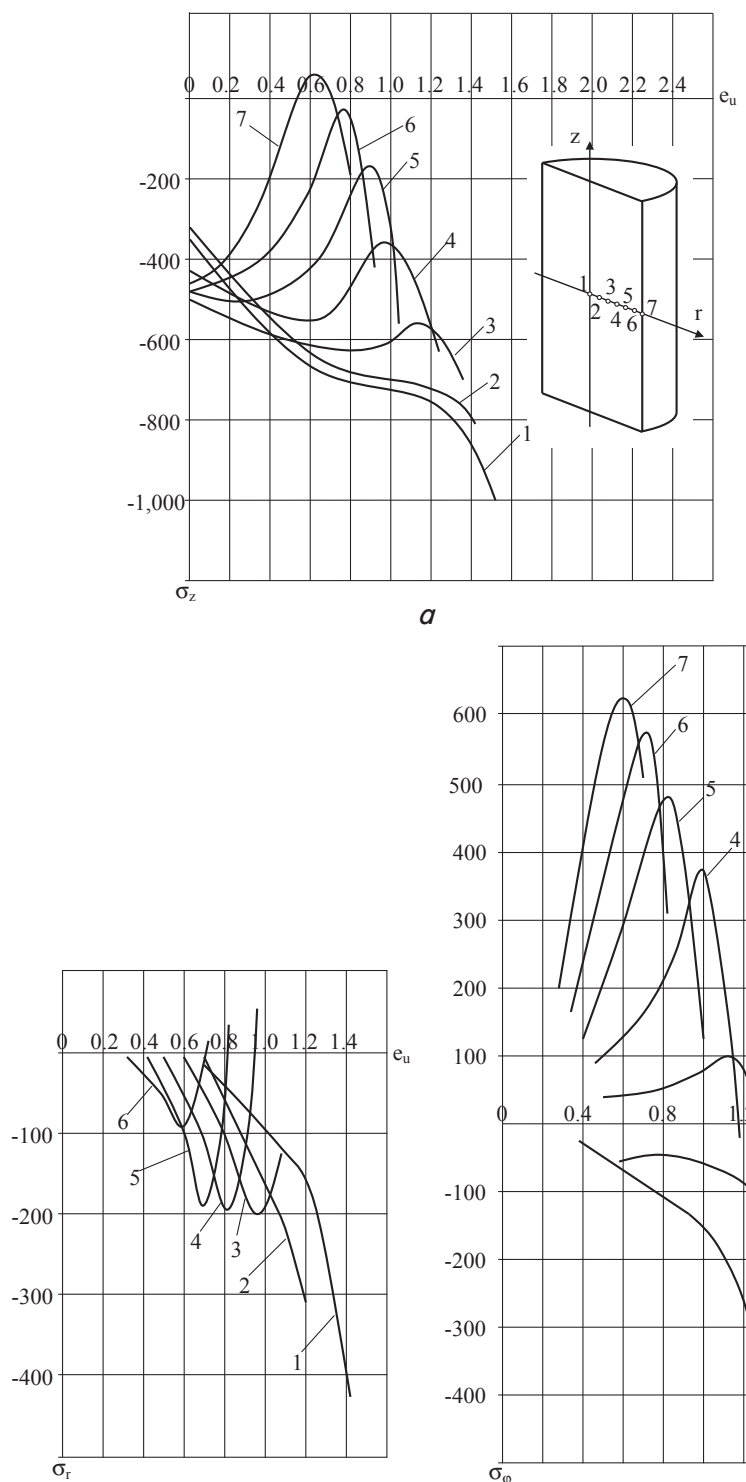

$b$

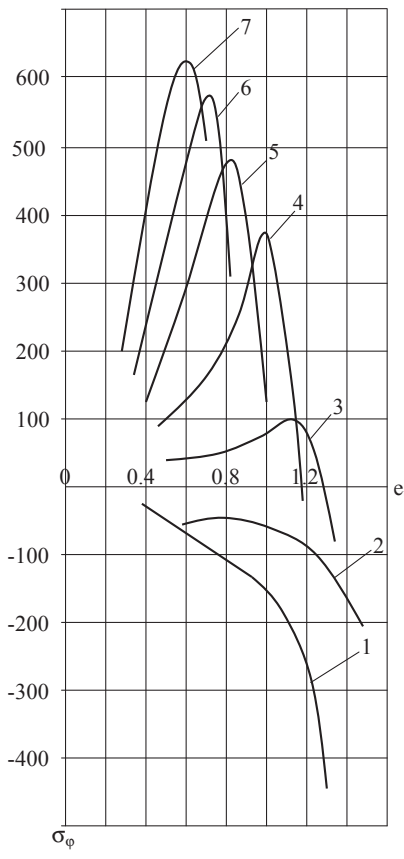

Fig. 5. The dependences of the normal stresses $\sigma_{z}, \sigma_{r}$, and $\sigma_{\varphi}$ on the degree of deformation $e_{u}$ at points 1-7: $a-\sigma_{z}$ on $e_{u}$;

$$
b-\sigma_{r} \text { on } e_{u} ; c-\sigma_{\varphi} \text { on } e_{u}
$$

From the analysis of the results given in Table 1, it follows that an increase in the rounding radius $\rho$ from $1 \mathrm{~mm}$ to $3 \mathrm{~mm}$ practically does not affect the value of the used plasticity resource at a hazardous point, and only at $\rho=5 \mathrm{~mm}, \psi$ decreases to 0.86 .

However, if the radius of the matrix rounding is less than $3 \mathrm{~mm}(\rho<3 \mathrm{~mm})$, the plasticity resource at the dangerous point is practically exhausted, and only at $\rho=5 \mathrm{~mm}$, a flange with a diameter of $d_{\max }=44 \mathrm{~mm}\left(d_{0}=20 \mathrm{~mm}\right)$ can be obtained without failure. In the experimental tests, a flare at the flange equator arises with a flange diameter of $d_{\max }=48 \mathrm{~mm}$ for a value of $\rho / d_{0}=0.25(\rho=4.26 \mathrm{~mm})$. The results of the calculations coincide satisfactorily with the results obtained in $[1-4,23]$.

The main advantage of this research is the rather high accuracy of determining the value of the used plasticity resource $\psi$. The disadvantage is the great complexity of calculations.

This study is useful and practically indispensable in assessing the ductility of a metal deformed under conditions of non-monotonic loading. The proposed calculation apparatus

can be used to evaluate the ductility of a metal in the most general cases of complex and non-monotonic loading.

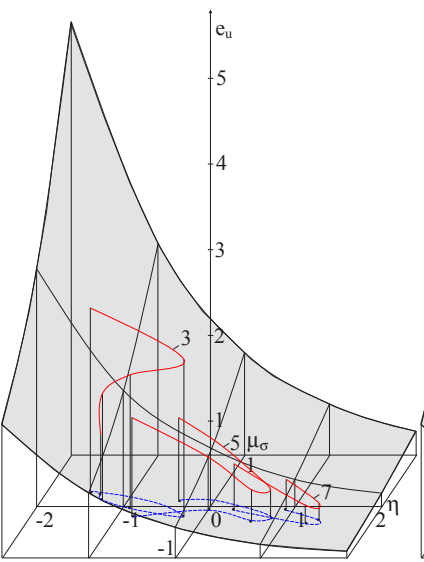

$a$

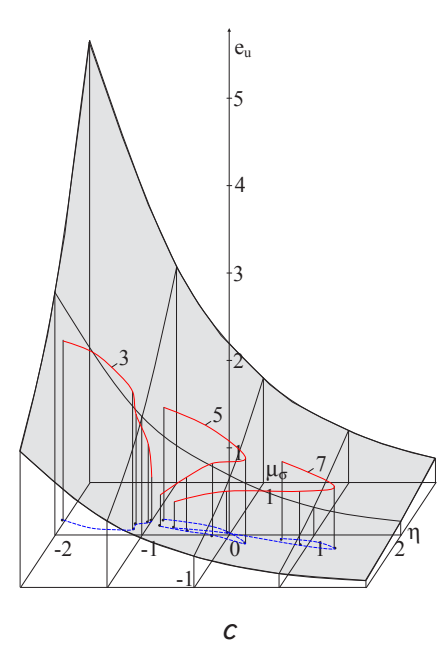

Fig. 6 . The surface of the limiting deformations $e_{p}\left(\eta, \mu_{\sigma}\right)$ for steel 10 and the deformation paths of the material particles at points 3,5 , and 7 : $a-\frac{\rho}{d_{0}}=0.05 ; b-\frac{\rho}{d_{0}}=0.15 ; c-\frac{\rho}{d_{0}}=0.25$

This work is a continuation of research in the field of ductility of deformed metals. In the future, these findings will be improved by refining the methods for calculating the stress-strain state and the methods of experimental studies, quantifying the damage accumulation rate, using the theory of dislocations, and taking account of structural transformations in the deformed metal.

\section{Conclusion}

1. The plasticity of metals under conditions of complex loading is estimated by creating a calculation apparatus that allows the components of the stress tensor to be calculated in the technological problems of metal working with pressure.

2. A calculation apparatus has been created that allows estimating the value of the used plasticity resource in the processes of metal working with pressure accompanied by non-monotonic loading, on the basis of analyzing the stressed state and the experimental determination of the mechanical characteristics of the metals under consideration. 


\section{References}

1. Zhbankov, I. G. New schemes of forging plates, shafts, and discs [Text] / I. G. Zhbankov, A. V. Perig, L. I. Aliieva // The International Journal of Advanced Manufacturing Technology. - 2015. - Vol. 82, Issue 1-4. - P. 287-301. doi: 10.1007/s00170-015-7377-7

2. Aliiev, I. Prediction of the variation of the form in the processes of extrusion [Text] / I. Aliiev, L. Aliieva, N. Grudkina, I. Zhbankov // Scientific and technical journal Metallurgical and Mining Industry. - 2011. - Vol. 3, Issue 7. - P. 17-22.

3. Aliieva, L. Radial-direct extrusion with a movable mandrel [Text] / L. Aliieva, Y. Zhbankov // Metallurgical and Mining Industry. 2015. - Issue 11. - P. 175-183.

4. Zhbankov, I. G. Calculation of recovery plasticity in multistage hot forging under isothermal conditions [Text] / I. G. Zhbankov, A. V. Perig, L. I. Aliieva // SpringerPlus. - 2016. - Vol. 5, Issue 1. doi: 10.1186/s40064-016-3570-x

5. Dunand, M. On the predictive capabilities of the shear modified Gurson and the modified Mohr-Coulomb fracture models over a wide range of stress triaxialities and Lode angles [Text] / M. Dunand, D. Mohr // Journal of the Mechanics and Physics of Solids. 2011. - Vol. 59, Issue 7. - P. 1374-1394. doi: 10.1016/j.jmps.2011.04.006

6. Driemeier, L. Experiments on stress-triaxiality dependence of material behavior of aluminum alloys [Text] / L. Driemeier, M. Brünig, G. Micheli, M. Alves // Mechanics of Materials. - 2010. - Vol. 42, Issue 2. - P. 207-2017. doi: 10.1016/j.mechmat.2009.11.012

7. Brünig, M. Biaxial experiments and phenomenological modeling of stress-state-dependent ductile damage and fracture [Text] / M. Brünig, S. Gerke, M. Schmidt // International Journal of Fracture. - 2016. - Vol. 200, Issue 1-2. - P. 63-76. doi: 10.1007/ s10704-016-0080-3

8. Assempour, A. A methodology for prediction of forming limit stress diagrams considering the strain path effect [Text] / A. Assempour, R. Hashemi, K. Abrinia, M. Ganjiani, E. Masoumi // Computational Materials Science. - 2009. - Vol. 45, Issue 2. - P. 195-204. doi: 10.1016/j.commatsci.2008.09.025

9. Le Maoût, N. Aluminum alloy damage evolution for different strain paths - Application to hemming process [Text] / N. Le Maoût, S. Thuillier, P.Y. Manach // Engineering Fracture Mechanics. - 2009. - Vol. 76, Issue 9. - P. 1202-1214. doi: 10.1016/ j.engfracmech.2009.01.018

10. Hora, P. Prediction of failure under complex 3D-stress conditions [Text] / P. Hora, L. Tong // Proceedings of Forming Technology Forum 2009. - 2009. - P. 133-138.

11. Damage Mechanics in Metal Forming [Text] / K. Saanouni, P. Devalan (Eds.). - John Wiley \& Sons, $2012 .-523$ p. doi: 10.1002/9781118562192

12. Ogorodnikov, V. A. Energiya. Deformatsii. Razrushenie (zadachi avtotekhnicheskoy ekspertizy) [Text] / V. A. Ogorodnikov, V. B. Kiselyov, I. O. Sivak. - Vinnytsia: UNIVERSUM-Vinnytsia, 2005. - 204 p.

13. Backhaus, G. Zur analytischen Darstellung des Materialverhaltens im plastischen Bereich [Text] / G. Backhaus // ZAMM Zeitschrift fûr Angewandte Mathematik und Mechanik. - 1971. - Vol. 51, Issue 6. - P. 471-477. doi: 10.1002/zamm.19710510608

14. Ohorodnikov, V. A. Modeliuvannia protsesiv nemonotonnoi plastychnoi deformatsii [Text] / V. A. Ohorodnikov, I. O. Sivak, R. I. Sivak // Knyha za materialamy piatoi mizhnarodnoi naukovo-tekhnichnoi konferentsii "Kontrol i upravlinnia v skladnykh systemakh" (KUSS-99). - 1999. - Vol. 1. - P. 195-197.

15. Hvan, D. V. Issledovanie deformatsionnoy anizotropii metallov pri nemonotonnom plasticheskom deformirovanii v usloviyah lineynogo napryazhyonnogo sostoyaniya [Text] / D. V. Hvan, O. A. Rozenberg, Yu. A. Tsekhanov // Problemy prochnosti. - 1990. Issue 12. - P. 53-56.

16. Hvan, D. V. Eksperimental'naya mekhanika konechnyh deformatsiy [Text] / D. V. Hvan, F. H. Tomilov, V. I. Korol'kov. - Voronezh: Izd-vo «ELIST», 1996. - 248 p.

17. Zav'yalov, Yu. S. Metody splayn-funktsiy [Text] / Yu. S. Zav'yalov, B. I. Kvasov, V. L. Miroshnichenko. - Moscow: Nauka, 1980. $352 \mathrm{p}$.

18. Ogorodnikov, V. A. Deformiruemost' i razrushenie metallov pri plasticheskom deformirovanii [Text] / V. A. Ogorodnikov. - Kyiv: UMK VO, 1989. - 150 p.

19. Kolmogorov, V. L. Napryazheniya, deformatsii, razrushenie [Text] / V. L. Kolmogorov. - Moscow Metallurgiya, 1970. - 230 p.

20. Bogatov, A. A. Resurs plastichnosti metallov pri obrabotke davleniem [Text] / A. A. Bogatov, O. I. Mizhiritskiy, S. V. Smirnov. Moscow: Metallurgiya, 1984. - $144 \mathrm{p}$.

21. Del', G. D. Plastichnost' deformirovannogo metalla [Text] / G. D. Del' // Fizika i tekhnika vysokih davleniy. - 1982. - Issue 11. P. 28-32.

22. Ogorodnikov, V. Plasticity of Metal Subjected to Complex Loading [Text] / V. Ogorodnikov, G. Del, L. Spiridonov // Izv. Vyssh. Uchebn. Zaved. Mashinostr. - 1974. - Issue 12. - P. 22-26.

23. Alieva, L. I. Resurs plastichnosti v protsessah kombinirovannogo vydavlivaniya [Text] / L. I. Alieva, I. A. Dereven'ko, R. I. Sivak // Obrabotka materialov davleniem. - 2013. - Issue 1 (34). - P. 11-17. 